Egyptian Journal of Aquatic Biology \& Fisheries

Zoology Department, Faculty of Science,

Ain Shams University, Cairo, Egypt.

ISSN $1110-6131$

Vol. 24(7): 233 - 258 (2020)

www.ejabf.journals.ekb.eg

\title{
Long-term evaluation of eutrophication problem using multi-sensor satellite data along El-Max Bay, Alexandria coast and Abu-Qir Bay, Egypt
}

\author{
Ali A. H. Abdelsalam ${ }^{1}$, Samy A. Saber ${ }^{2}$, Sameh B. El-Kafrawy ${ }^{1}$ and \\ Hamdy A. H. Abo-Taleb ${ }^{2} *$ \\ 1. National Authority for Remote Sensing and Space Sciences, Egypt \\ 2. Faculty of Science, Al-Azhar University, Nasr City 11823, Cairo, Egypt \\ * Corresponding author: voalia@yahoo.com
}

\section{ARTICLE INFO \\ Article History: \\ Received: Sept. 3, 2020 \\ Accepted: Oct. 23, 2020 \\ Online: Oct. 25, 2020}

\begin{abstract}
The Alexandria coastal water and Abu Qir Bay are subjected to Spatio-temporal variations in their primary productivity and physical-chemical properties both on a short and long-term basis because of continuous and ever-increasing discharge of organic and inorganic from urban supplies and sewage collection systems.

Chlorophyll-a (Chl-a) concentration, expressing phytoplankton biomass, is considered a good indicator of the water's trophic state. In the present study, the average daily, monthly, seasonal, and annual means of reading of Chl-a were obtained between 2000 and 2019 from multi-satellite sensors to characterize the Spatio-temporal variation of phytoplankton in the Egyptian coastal area.

Our results showed that phytoplankton anomalies varied spatially and temporally. The study recorded a remarkable increase of Chl-a during the period from May to September (spring and summer) each year, summer readings were higher than spring. Annual Chl-a data showed an upward tow trend, the first was from the year 2000 to 2010, the second and the highest trend was from 2011 to 2019 , occurs after the revolution of January 25,2011 . Overall, the study period of Chl-a reaches its maximum values $(35 \mathrm{mg} / \mathrm{m} 3)$ during 2015 at Abu Qir Bay and $40 \mathrm{mg} / \mathrm{m} 3$ at El-Max Bay during 2019. The Chl-a concentration was high and more pronounced near the outlets of the Egyptian coastal lakes and urban outfalls, especially at El-Max Bay and Abu Qir Bay compared to the Alexandria shore area. There was a very low positive correlation between the Chl- $a$ and sea surface temperature (SST), on the other hand, the correlation between Chl- $a$ and the diffuse attenuation coefficient KD_(490) seems to be strongly positive and it was strongest with Colored dissolved organic matter (CDOM), as well as the correlation between $C h l-a$ and nitrate and phosphate was strongly positive.
\end{abstract}

\section{INTRODUCTION}

Over the past few decades, some Mediterranean coastal areas were subjected to the enrichment of water by nutrients, especially nitrogen, phosphorous and organic matter, causing increased algae and higher plant life forms, this phenomenon is known as 
eutrophication, according to Andersen et al. (2006). Eutrophication has become a significant worldwide problem of water pollution that catastrophically affects aquaculture and local economies (Richlen et al., 2010). In general, nutrient over-enrichment results tend to be negative, with beneficial effects being rare or accidental (Fisher et al., 1995). Also, eutrophication has a highly negative economic dimension (Segerson and Walker, 2002). A harmful algal bloom is the expected result of the eutrophication problem.

The problem of eutrophication on the Egyptian Mediterranean coast is mainly due to large amounts of wastewater discharged by land-based effluents from the Nile River, agriculture and sewage water directly or indirectly linked to the Mediterranean coastal region via coastal lakes (Ansari et al., 2011).

Alexandria, Egypt's largest city on the Mediterranean coast, is one of the most important industrial centers, comprising about 100 large factories (Abd-Alla, 1993). Eutrophication was recorded for the first time along El-max Bay of Alexandria in 1985 (Dorgham, 2011). De Jonge et al. (2002) reported that eutrophication levels increased over the past two decades. The Western Harbor is also subjected to continuous environmental changes due to the intensive maritime activities and the significant amounts of wastes discharged daily (Gharib and Dorgham, 2006). Also, because of the continuous movement of the lake's water toward the Mediterranean Sea (Khalil, 2014). Abu Qir Bay, a shallow semi-circular basin and a fertile marine habitat, is used for commercial fishing, shipping, recreational boating, swimming, and as a repository for sewage effluents (Said $\boldsymbol{e t}$ al., 1995). The importance of the Abu Qir site and its suffering from different sources of pollution thirst many researchers to study its biological, ecological, and pollution issues (Abdel-Moneim and Shata, 1993; El-Deek, 1995; Youssef and Masoud, 2004; Abd Allah et al., 2006; Kholeif, 2008).

Chlorophyll-a, a measure of phytoplankton biomass, is commonly employed as an indicator of eutrophication (Bricker et al., 1999). The response of phytoplankton biomass to increased nutrient input comprises a major pathway in many conceptual models of eutrophication (Cloern, 2001).

Over the past two decades, ocean color remote sensing measurements have provided unique information on marine productivity. The ocean's color is a good indicator of the primary photosynthetic pigment found in phytoplankton, chlorophyll-a (Dierssen, 2013). and can provide accurate spatial distribution and Time-series analyses (ElKafrawy et al., 2015; El Kafrawy, 2017; El-Zeiny \& El-Kafrawy, 2017). Information of space and time variability of phytoplankton biomass in oligotrophic to ultraoligotrophic conditions is key to understanding the dynamics of the marine environment (Mann and Lazier, 2006). Many studies have shown that time series of remotely sensed data might provide information on growth patterns of phytoplankton and associated environmental conditions (Brando et al., 2012; Devlin et al., 2012; Kennedy et al., 2012; Schroeder et al., 2012). Earlier Mediterranean studies, e.g., Bricaud et al. 
(2002). The recognized international National Aeronautics and Space Administration NASA algorithms empirical ocean color version $4(\mathrm{OC} 2 \mathrm{v} 4)$ and $\mathrm{OC} 4 \mathrm{v} 4$ have shown that the satellite-derived $\mathrm{Chl}-\mathrm{a}$ concentration in coastal areas is substantially overestimated and uncertain. (Bosc et al., 2004). The Mediterranean ocean color MedOC4 algorithm is most for the Mediterranean waters suited (Volpe et al., 2007).

Most of the previous studies were based on seasonal or bimonthly sampling. However, the rapid changes in water quality and biotic components require frequent follow-up at shorter time intervals. Lavender et al. (2009) studied ocean colour satellite analysis between 1997 and 2006 and confirmed the return of the Nile bloom and its predominance along the whole Nile Delta shelf. So, the processing of water samples by ships is often expensive and offers minimal data in space and time.

On the other hand, satellite remote sensing can cover wide areas (up to global) with reasonably high resolution $(250 \mathrm{~m}-1 \mathrm{~km})$ and without national boundaries being limited. In addition, Therefore, complementing traditional ship-based monitoring approaches with satellite remote sensing techniques is appropriate. Collectively, remote sensing data will provide a wide visual picture of oceanic phenomena with frequent ship tracking, supporting our understanding of eutrophication processes and evaluating coastal ecosystems' health. Long-term series (nearly 40 years) of regularly measured (up to several days) are given by remote sensing. Recent advances in remote sensing have allowed Chl-a concentration, colored dissolved organic matter (CDOM), primary phytoplankton productivity, and sea surface temperature (SST) data and information to be collected (CEARAC, 2005). Thus, it is reasonable to complement conventional shipbased methods of monitoring with satellite remote sensing techniques. Collectively, with regular ship monitoring, remote sensing data can provide a broad visual image of oceanic phenomena, aiding our understanding of eutrophication processes and assessing coastal environments' health.

The present work aims to use optical remote sensing data to assess the process of eutrophication along with Alexandria and Abu Qir Bay and provide a comprehensive view of some environmental parameters to fill the gap of the insufficient field data over twenty years. Time-series data gathered by the ocean color multi-sensor was chosen to explore the large scale between 2000 and 2019. A temporary trend in annual, seasonal, and monthly climatology will be presented. Finally, with sea surface temperature ( SST), colored dissolved organic matter (CDOM), and the diffuse attenuation coefficient at 490 $\mathrm{nm}$ (Kd 490), spatial mapping, and comparison with the results of previous research, the spatiotemporal trends resulting from this study will be addressed simultaneously. 


\section{MATERIALS AND METHODS}

\section{Study Area}

The Egyptian Mediterranean Coast receives a massive amount of irrigation water from the River Nile, its canals, and drains (Fig. 1). El-Max Bay, Alexandria Coastline, and Abu Qir Bay have been included in the research regions. (Fig. 2). El-Mex Bay is a relatively wide coastal bay west of Alexandria, with an average depth of $10 \mathrm{~m}$ and a surface area of $19.4 \mathrm{~km} 2$ (El- Sherif, 2006, Aboul Ezz et al., 2014 and Abo-Taleb et al., 2015). Alexandria coastline extends from the port of Dekhila west to the Gulf of Abu Qir east. The Abu Qir bay is a shallow semi-circular basin and is one of the most polluted areas along the Egyptian Mediterranean coast. It extends between Longitude $30^{\circ} .07$ and $30^{\circ} 22 \mathrm{E}$ at Abu Qir Peninsula and Latitude- $31^{\circ} .20 /-31^{\circ} 29 \mathrm{~N}$ at Rosetta Branch of River Nile (Fig. 2). It runs along a shoreline of about $50 \mathrm{~km}$ with an area of $360 \mathrm{~km}^{2}$, the maximum depth of the Bay is $9 \mathrm{~m}$, with an average of $3.8 \mathrm{~m}$ (Saad and Younes, 2006). The Bay receives agricultural drainage water from Lake Edku through Boughaz ElMaadya (about $200 \mathrm{~m}$ long and $2 \mathrm{~m}$ deep) with an annual average of $1000 \times 10^{6} \mathrm{~m}^{3}$ (Saad and Younes, 2006 and El-Damhogy et al., 2019). Besides, about $1.2 \times 106 \mathrm{~m}^{3} / \mathrm{d}$ freshwater is discharged into the Bay through Rosetta's mouth at the extreme eastern edge (Faragallah, 2004).

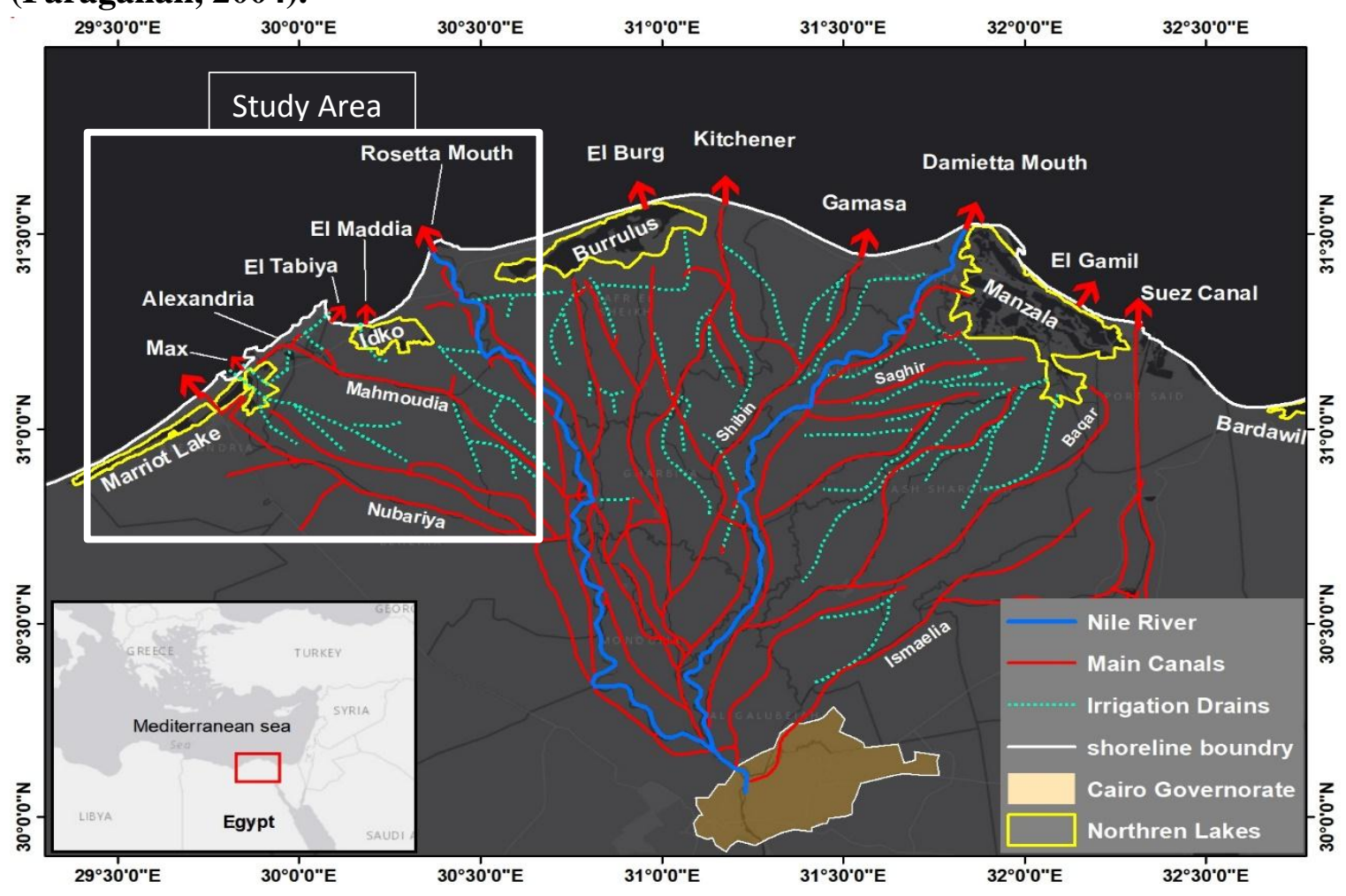

Fig. 1. Dark image for the Nile delta showing the coastal lakes, Rosetta and Damietta branches of the Nile River, and the intensive irrigation canals and drains, red arrows indicate major urban outfalls, drains, and lakes outlets along the delta coast. 


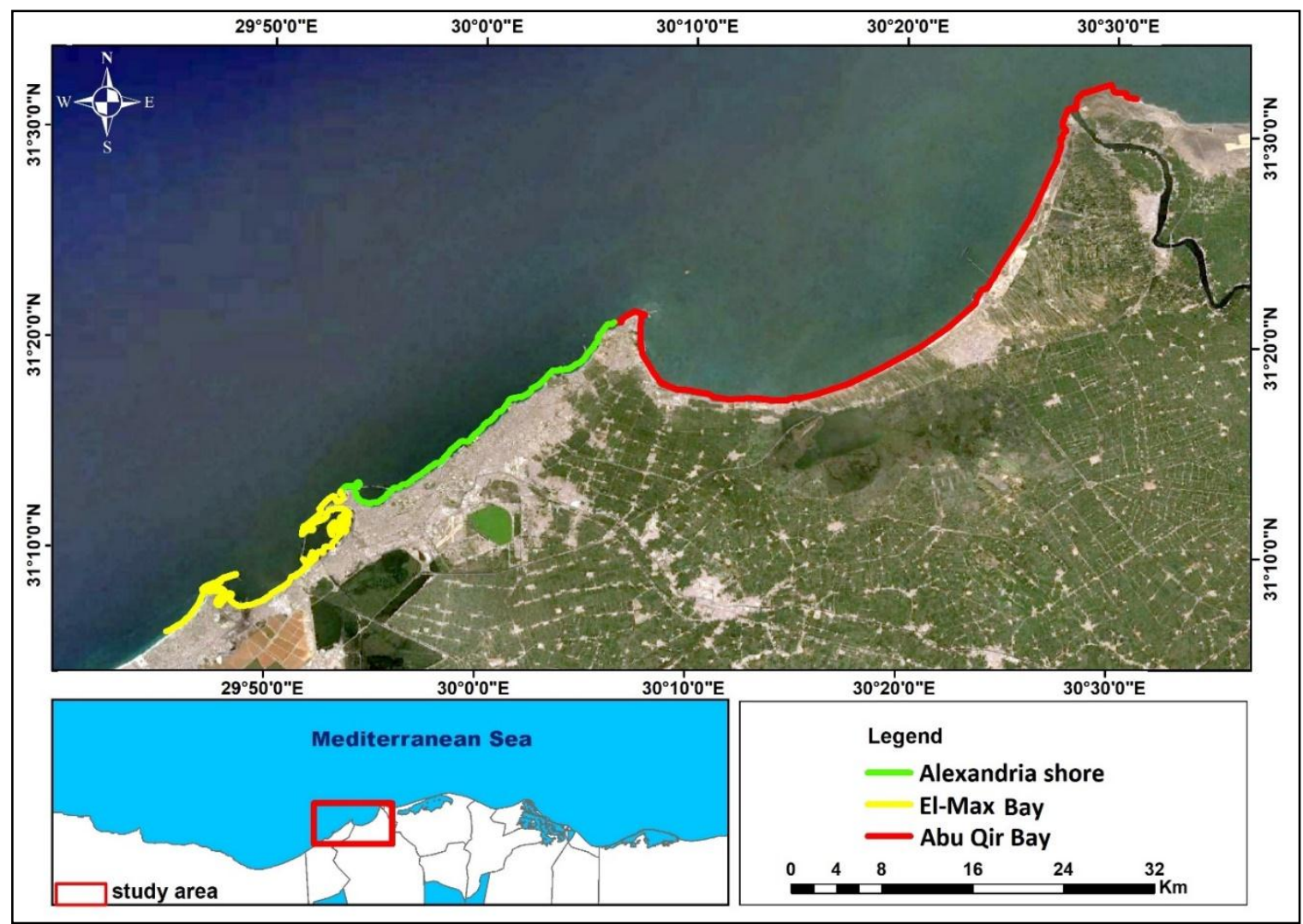

Fig. 2. A map shows the location of the studied biogeographical areas along the Egyptian Mediterranean Coast.

\section{Data and bio-optical algorithm}

The study used an 8-days/monthly long time series (20 years; Sep 2000 to Dec 2019) of NASA ocean colour data merged from three satellite data sources (SeaWiFS, MODIS AQUA, and MERIS).

In the present work, surface Chl- $a$ was computed by applying the medOC4 regional biooptical algorithm to fully normalized reflectance products $(\rho)$. At the horizontal spatial resolution of 1 kilometer, the regular OC4 algorithm returns close-surface Chl-a in mg $/ \mathrm{m}^{3}$. Calculated using an equilibrium model derived from in-field observations of waterleaving satellite data reflectance (Rrs) ratios of Chl-a and blue-to-green bands formed by O'Reilly et al. (1998) and described as the following:

$$
\log _{10}(c h-a)=0.2424-2.7423 R+1.8017 R^{2}+0.0015 R^{3}-0.1228 R^{4}
$$

With

$$
R=\log _{10}\left(\frac{\operatorname{Max}\left(\operatorname{Rrs}_{443}, \operatorname{Rrs}_{488}\right)}{\operatorname{Rrs}_{547}}\right)
$$

Satellite detection for SST calculation is achieved by detecting ocean radiation at two or more wavelengths within the infrared part of the electromagnetic spectrum that can be 
experimentally related to SST. In this case, the MODIS SST product provides a sea surface temperature of 1 kilometre at a geographical resolution.

The Kd $4901-\mathrm{km}$ resolution is measured using an experimental model derived from in situ radiometric spectral data from $\mathrm{Kd} 490$ coastal stations and blue-to-green band ratios of satellite data reflectance (Rrs) for a range of water forms. (Austin and Petzold, 1981).

Satellite data from the SeaWiFS, MODIS, and MERIS sensors were used to evaluate and parameterize CDOM empirical algorithms using Rrs visible bands; specifically, the performance of the algorithm using the $\operatorname{Rrs}(490) / \operatorname{Rrs}(555)$ band ratios were used to derive CDOM (Mannino et al. 2008).

Filed annual nitrate and phosphate data were acquired from the EIMP (environmental information and monitoring program.

\section{Processing and software's}

For each parameter, about 8079 daily images were performed while merging daily images of ocean colour sensors to select and preserve the highest - quality pixels. Due to multiple quality levels 2, flags and masks processed on SeaDas, the best potential set of pixels, compatible with the masks used for Level 3 aggregated items on the oceancolor.gsfc.nasa.gov website. The binning method is based on NASA's SeaWiFS binning data operator, providing the ability to integrate pixel data into arithmetic mean using a geographic information system (GIS) confining a location to each pixel in a Level 3 map. Ultimately, the product resulting from this phase is a monthly, seasonal, and annual binned time series with $1 \mathrm{~km}^{2}$ resolution.

Hovmoller plots (latitude-/longitude-time plots) were then computed to illustrate and help explain the changes over time and space research regions for the two chosen clusters. Hovmoller diagrams provide a synoptic view of each satellite imagery product's Spatio-temporal variability, daily mean value throughout each latitude bin, or longitude bin for each cluster was measured. In this computation, the proportion of non-masked pixels was considered.

We analyzed satellite chlorophyll-a concentration Spatio-temporal heterogeneity, aggregating data with different temporal granularities. Using various descriptive statistics, such as mean, minimum, and maximum values, we aggregated data across the entire study period, annually, seasonally, and monthly. We have built up monthly and seasonal climatologists for the whole period studied (2000-2019): monthly, seasonally, and annual trends.

All the raster processing has been done in Arc GIS 10.7, which can be used for geospatial data production, analysis, and mapping. 


\section{RESULTS}

\section{Temporal analysis}

(Fig. 3) displays the average monthly readings of Chl-a concentration during 2000-2019 along the study area. Results showed that the Chl- $a$ curve peak was recorded during July for the El-Max area and Alexandria, with Chl-a average was $14 \mathrm{mg} / \mathrm{m}^{3}$ and $9 \mathrm{mg} / \mathrm{m}^{3}$, respectively. While at Abu Qir bay, the peak was during September with Chl-a average of $16 \mathrm{mg} / \mathrm{m}^{3}$. On the other hand, Chl- $a$ recorded its lowest values during December, January, and February of each year in the three regions.

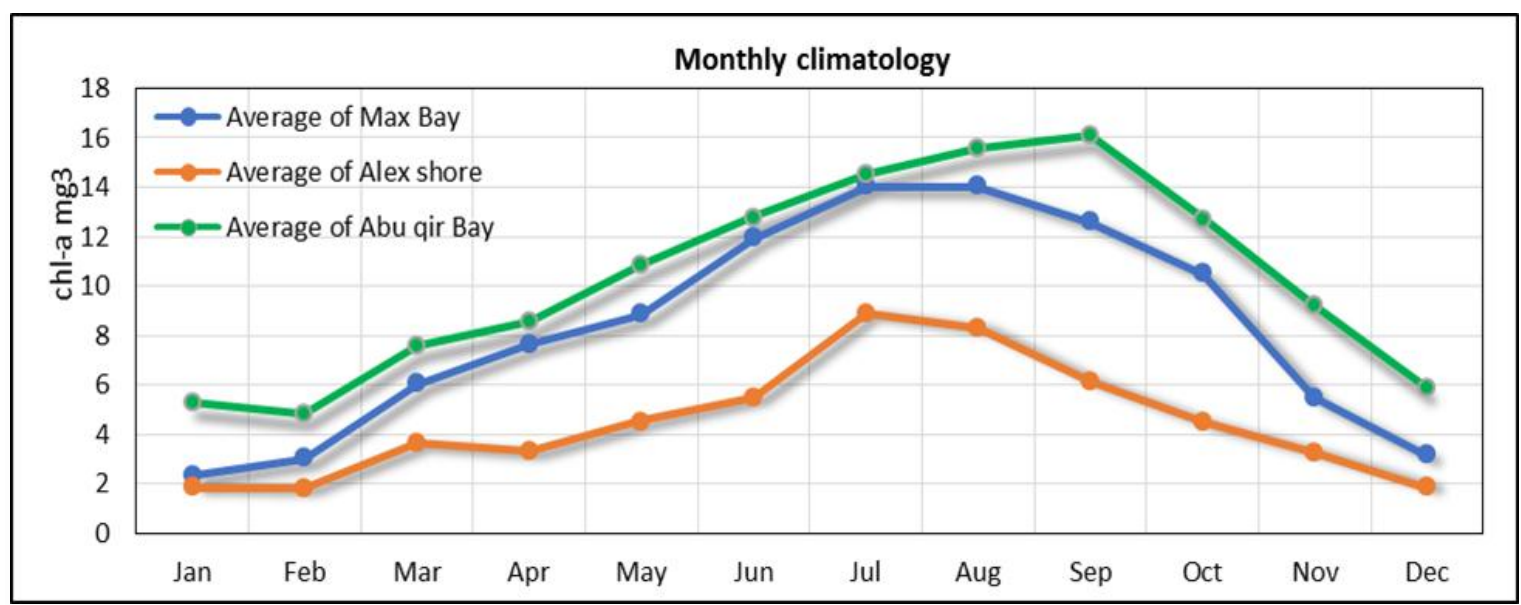

Fig. 3. 20-years of average monthly climatology of Chl-a concentration of three areas along the study area of the Egyptian Mediterranean Coast.

(Fig. 4) illustrates that along with the three regions, the average readings of Chl-a started to increase in the spring, reaching its highest concentration in the summer throughout the study period (20 years). Summer showed the bloom of Chl-a in all regions. While the pattern clearly showed the decreasing of the values during winter and autumn. It was noticed that there was an unusual increase in Chl- $a$ at El-Max Bay during 2019.

The monthly average of Chl-a for each different year from 2000 to 2019 is illustrated in (fig. 5 and 6), the averages of Chl-a are shown in the form of a periodic spectral curve and the peaks appear once a month or twice at all areas with the same pattern during July of each year and sometimes rise to appear in September, Values decrease in the period from the end of November to the beginning of April each year. It is clear that the levels of Chl-a constantly increase, but the increasing trend after 2010 greatly differs 
from that before 2010, where the monthly average of the Chl-a for the El-Max area reached $40 \mathrm{mg} / \mathrm{m}^{3}$. This increase is abnormal compared to before 2010 (the maximum record was $16 \mathrm{mg} / \mathrm{m}^{3}$ ), which is the same for the rest of the study areas. The ratio of highness for each region differed. The Alexandria Beach area recorded the lowest rate and the lowest values, while the El-Max region was lower than the Region of Abu Qir until 2016 then began to increase in 2017. Its values rise above the values of the Gulf of Abu Qir.

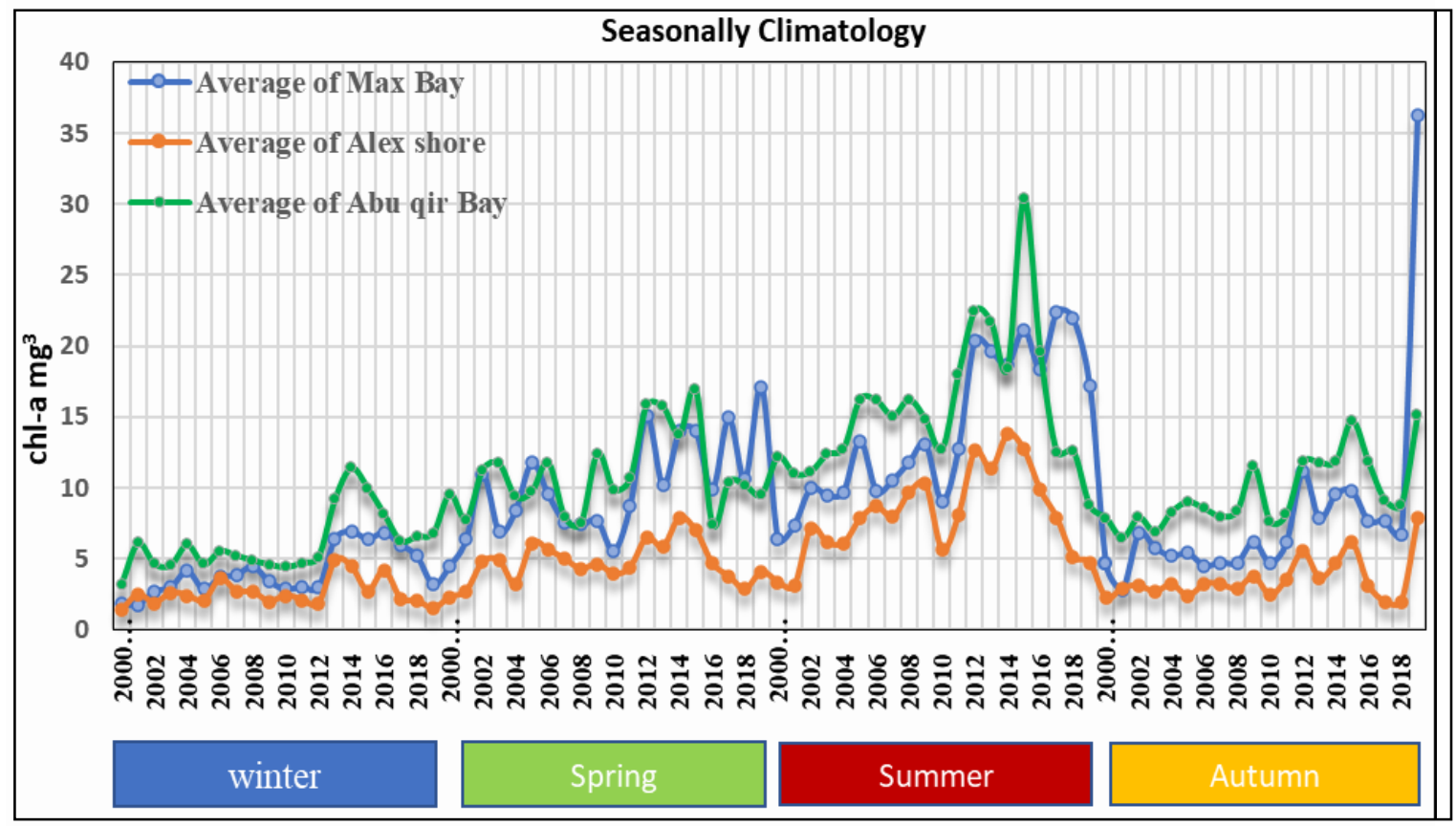

Fig. 4. Seasonally climatology of Chl- $a$ concentration for three studied regions. 


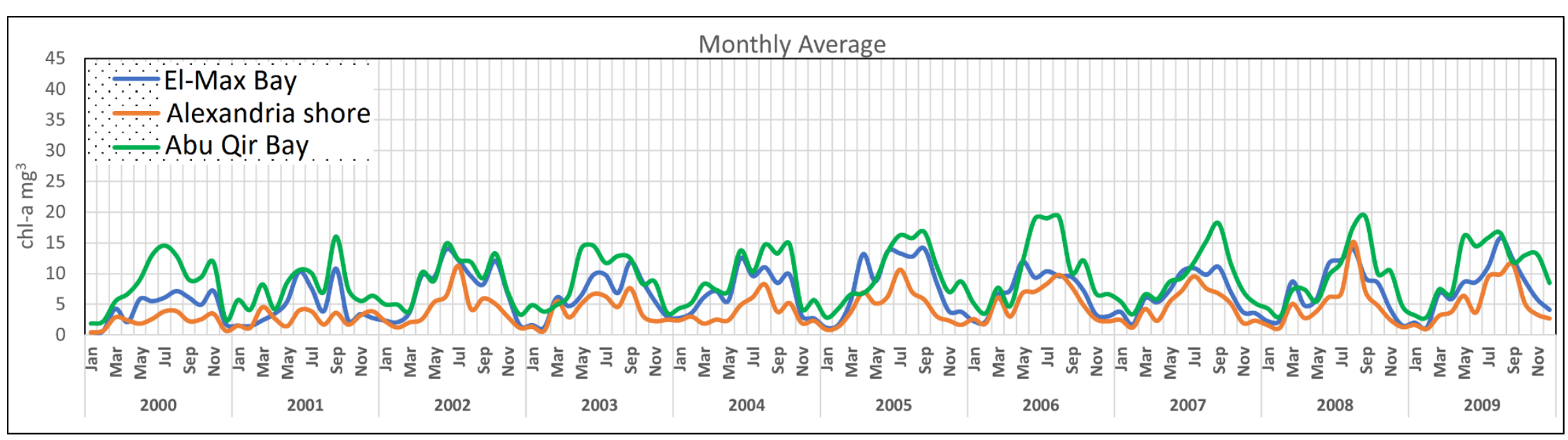

Fig. 5. monthly mean of time series variance of $C h l$ - $a$ concentration from 2000 to 2009 of three study regions.

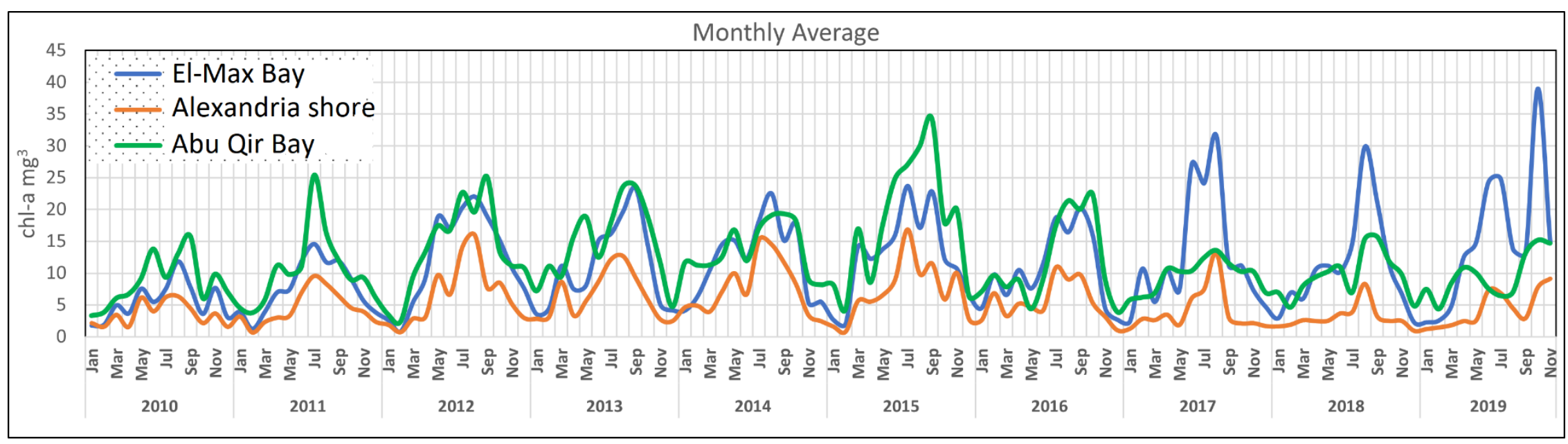

Fig. 6. Monthly mean of time series variance of Chl- $a$ concentration from 2010 to 2019 of three study regions. 


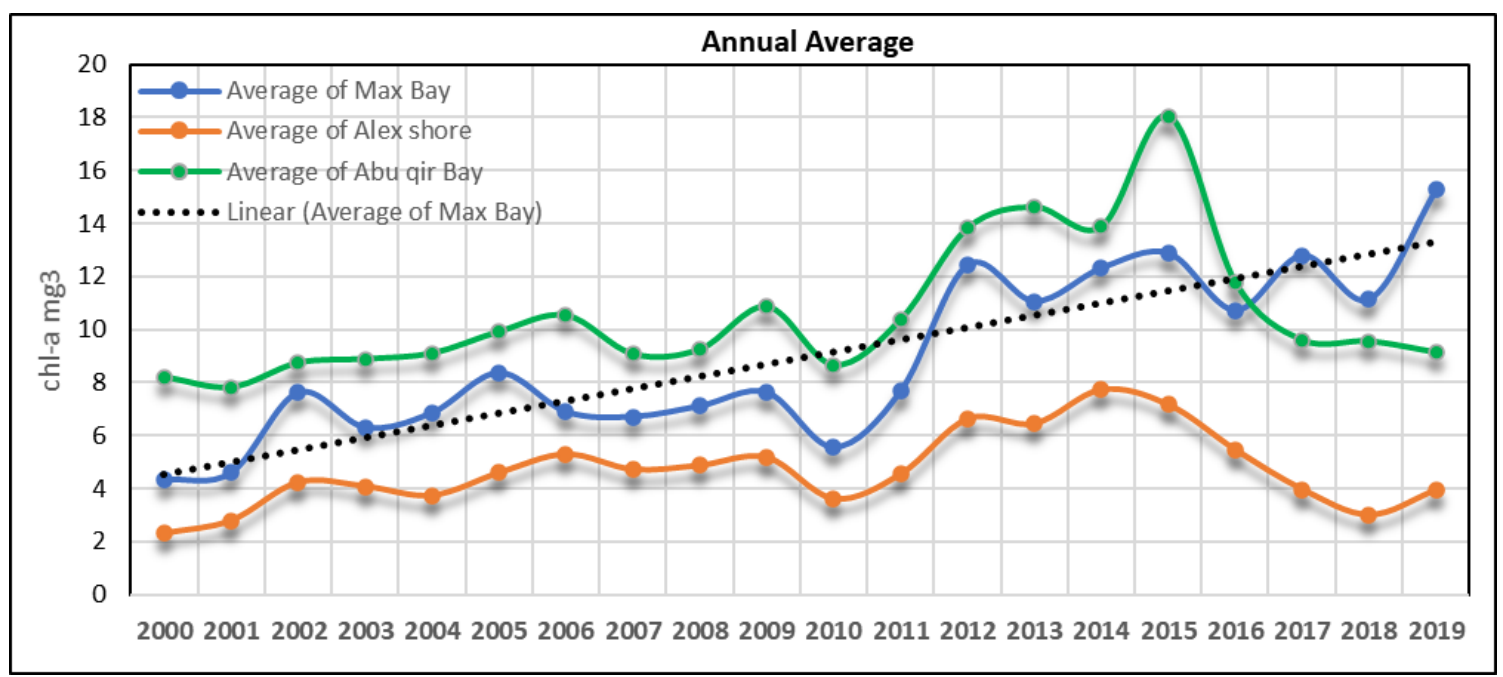

Fig. 7. Annual average of chlorophyll-a concentration of the three study regions.

The annual values $C h l-a$ have been varied for the three areas, and the average of $C h l-a$ recorded the highest readings during 2015 while its lowest levels were during 2000 and 2001. The changing in the annual trend of the Chl-a was relatively low until 2010, which was a turning point for $C h l-a$ levels that have been accelerated in the rate of increasing to reach an average of $18 \mathrm{mg} / \mathrm{m}^{3}$ in 2015 for the area of Abu Qir and $13 \mathrm{mg} / \mathrm{m}^{3}$ at El-Max. The turning point for the Alexandria beach area was the year 2014 (Fig. 7).

\section{Spatial analysis}

The annual distribution of Chl- $a$ along the study area indicated a predominant blooming of phytoplankton in the coastal area (Fig. 8). This blooming was stronger and more pronounced near the outlets of the Egyptian coastal lakes and urban outfalls. In the offshore area, the bloom occurred in the summer and spring, while in the other seasons, it was oligotrophic (Fig. 10). The long-term observation verified that the Chl- $a$ had been shifted spatially at El-Max Bay and Alexandria shore area, but it is constant at Abu Qir bay. (Fig. 9) demonstrates the mean monthly climatology of Chl-a variations at the surface water of the three studied areas. The coastal regions have a high $C h l-a$ concentration $\left(\sim 3\right.$ to $\left.15 \mathrm{mg} / \mathrm{m}^{3}\right)$ compared to the outer shelf and open seawater $(0.03$ to $3 \mathrm{mg} / \mathrm{m}^{3}$ ). 

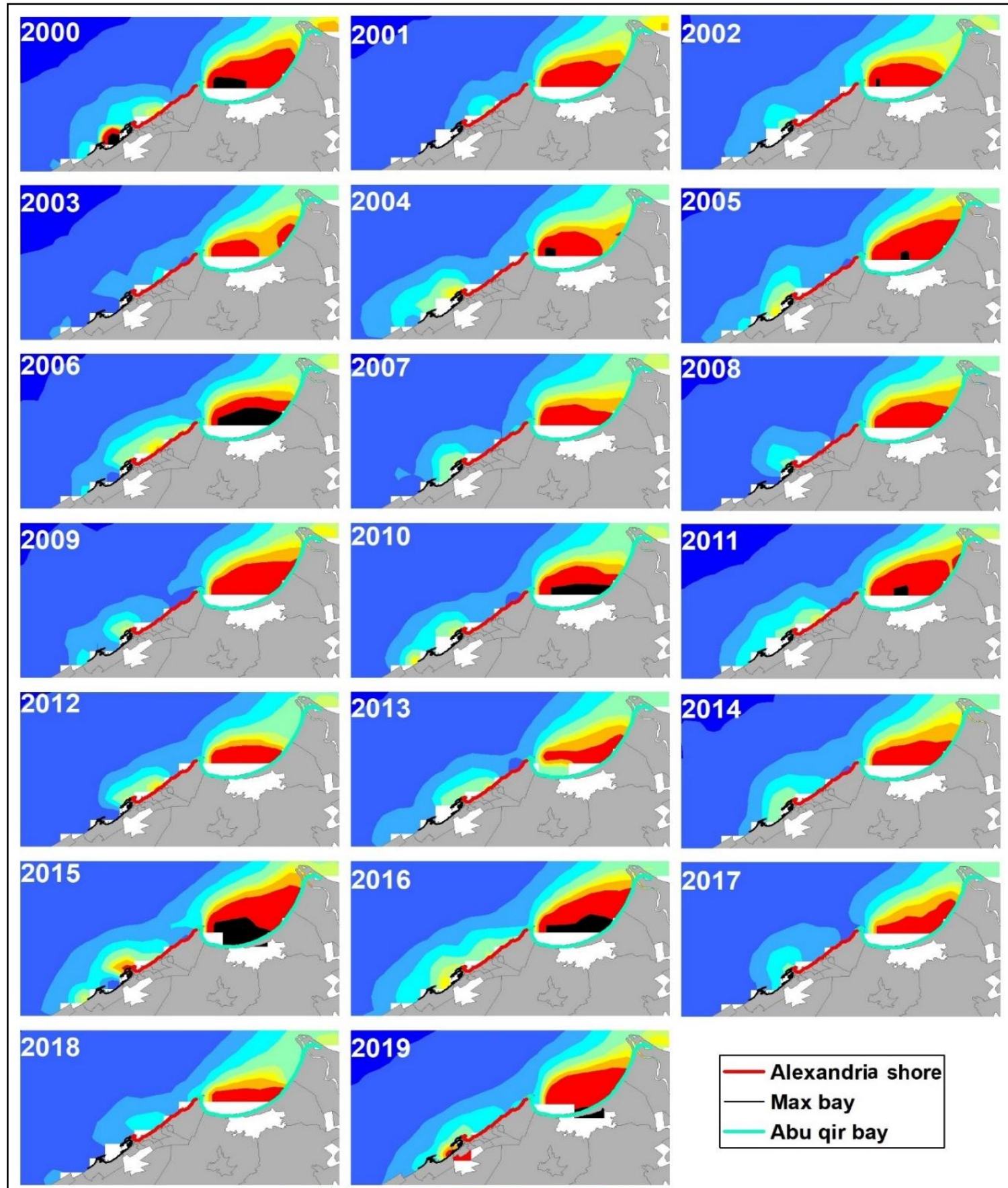

Chl-a

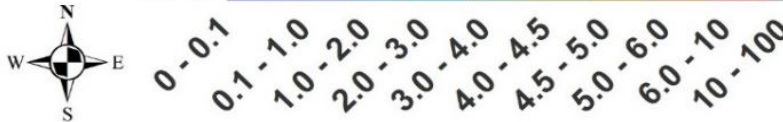

$\mathrm{mg} / \mathrm{m} 3$

Fig. 8. Annual mean of Chl-a concentration in the study areas from the year of 2000 to 2019. 


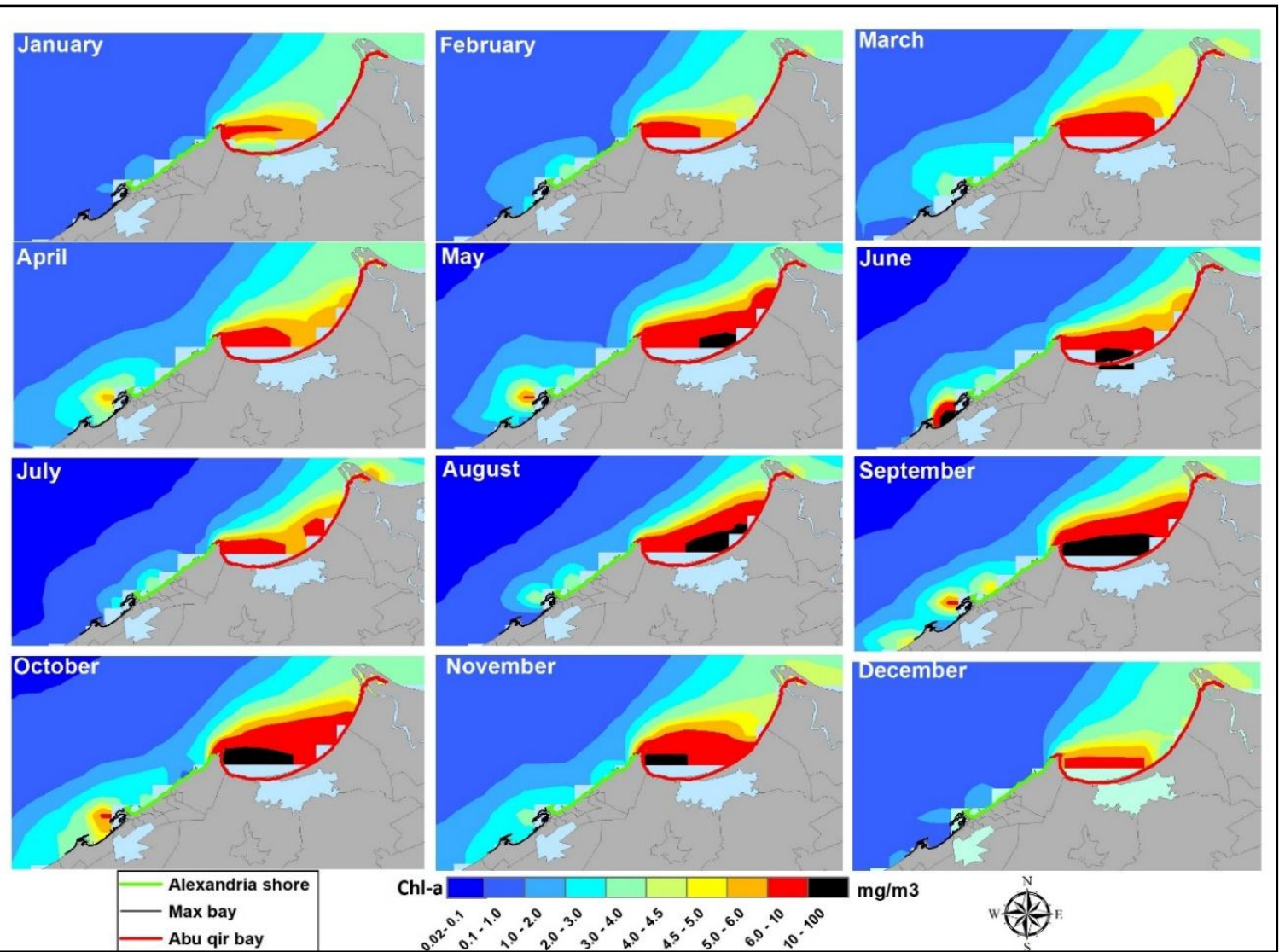

Fig. 9. Spatial coverage shows the monthly mean climatology of $C h l-a$ concentration from 2000 to 2019.

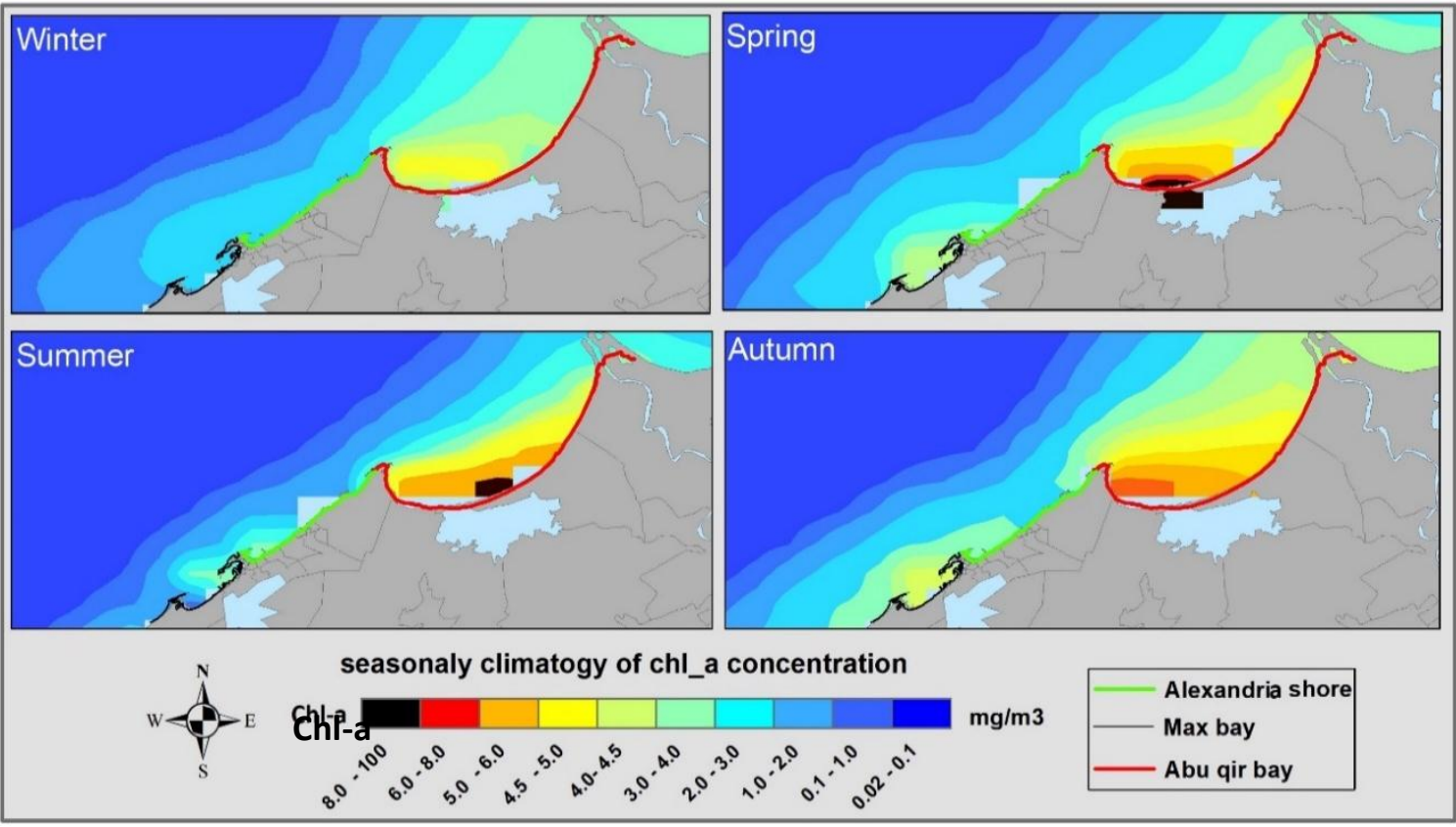

Fig. 10. Spatial coverage of seasonally mean climatology of Chl-a concentration during the years 2000 to 2019 . 


\section{Hovmoller analysis}

The Spatio-temporal history of Chl-a, FLH, SST, and CDOM is presented in (Fig. 11) for the three regions. Overall, a regular annual pattern can be seen in all diagrams with some differences depending on the satellite product. The $C h l-a$ seasonality displayed in the Hovmoller Fig. reflects that, of the tile-plots, there was an observed increase in Chl-a over the years, mostly between $31.26-31.38^{\circ} \mathrm{N}$ it was opposite of Abu Qir area, and a small value observed at El-Max area while the smallest level has been found at Alexandria shore. The diagram showed that the highest phytoplankton blooming has occurred during 2015 . This increase in Chl-a seasonality tends to extend towards $31.36^{\circ} \mathrm{S}$ after the year 2010 .

The fluorescence line height( FLH) (Fig. 11) displays regular seasonal patterns of Chl-a, with more significant increases outside of the seasonal peaks. A seasonal increase in FLH $\left(\sim 0.1-1 \mathrm{~mW} \cdot \mathrm{m}^{-2} \cdot \mathrm{sr}^{-1} \cdot \mathrm{nm}^{-1}\right)$ occurs regularly between October and March, and peaks between January and March (winter season). Spatially, FLH patterns in the Hovmoller also reflect the distribution of Chl-a. Temporally, Chl-a and FLH tend to increase over the years. It increases in El-Max to $31.26^{\circ} \mathrm{N}$ but becomes low in the Abu Qir area and intermediate ranges in the Alexandria shore area.

The KD-490 (Fig.11) displays the annual changes between $31.22-26^{\circ} \mathrm{N}$. KD's high values were observed at $31.26-38^{\circ} \mathrm{N}$ opposite to Abu Qir Bay and slightly increased at 31.16-22 N opposite to El-Max Bay during the years 2000, 2019. The KD. Trend was exactly like $C h l-a$.

The SST (Fig. 11) displays mild changes over the studied years, but there was a seasonal change where the highest value was observed in summer 2015 while the lowest was during 2013. Between 31.16-22 (El-Max Bay) was the highest comparing with other regions where the highest values were recorded during 2015 and 2016, like the trend of Chl- $a$ in the same years.

Hovmoller analysis showed that Chl- $a$, KD, and SST have a similar increase in the same area and time, but FLH shoed an inverse relation to the previous factors in the same regions, the distribution of parameter is high at Abu Qir Bay than El-Max and Alexandria shore which have the lower values of parameters related to $C h l-a$. 


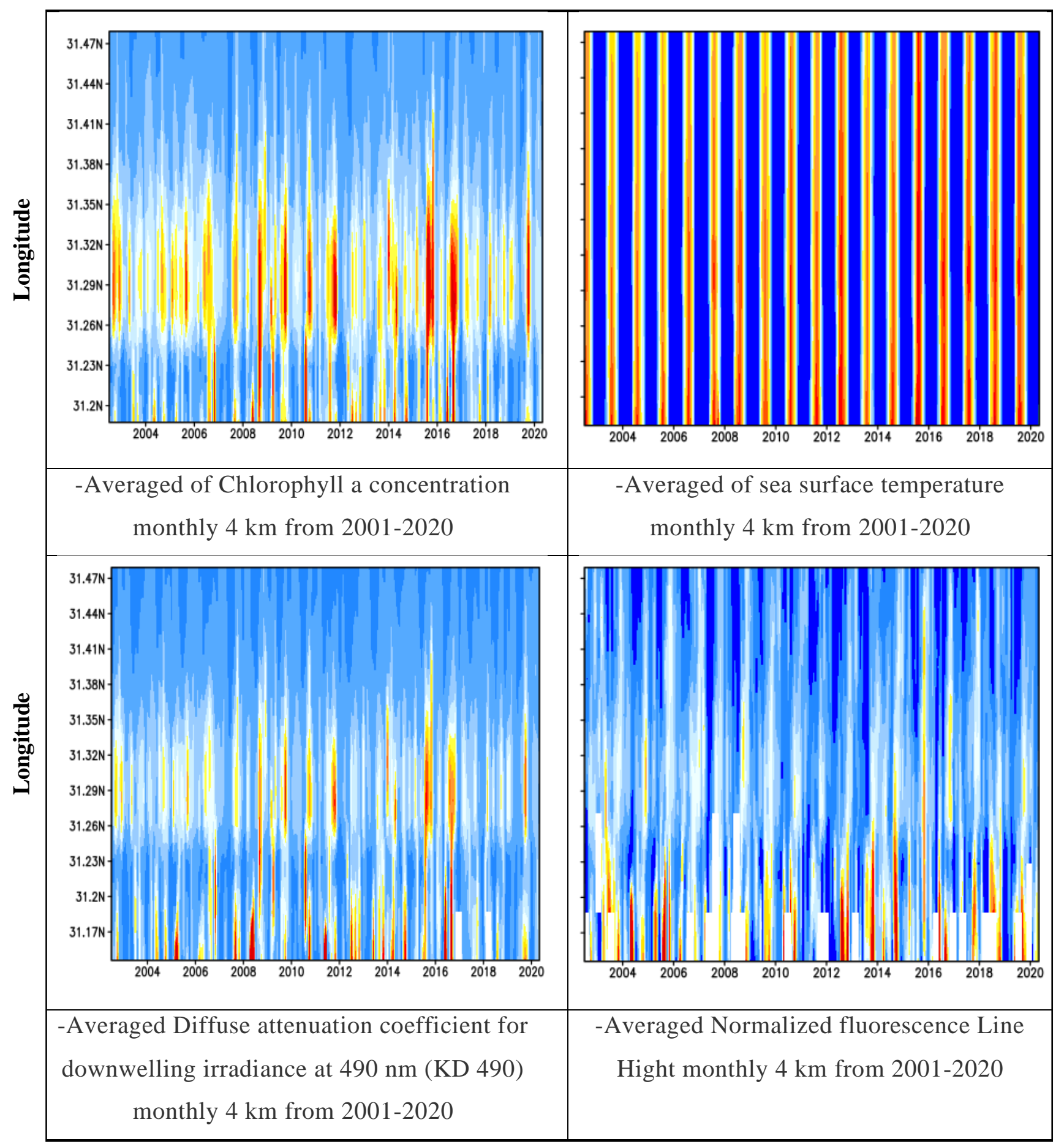

Fig. 11. The longitudinal $\left(31.17\right.$ to $\left.31.47^{\circ} \mathrm{N}\right)$ averaged Hovmoller plot showing the time-series distribution of multi sensor-retrieved Chl-a during the years 2000 to 2020. 


\section{Pearson correlation}

\subsection{Sea surface temperature (SST) and Chl-a}

Generally, there was a low correlation between SST and Chl-a at the study areas where the highest factor $(\mathrm{r}=0.17)$ was recorded at El-Max Bay (179 points), followed by $\mathrm{r}=$ 0.15 (772 points) at Abu Qir Bay and finally, the lowest value ( $r=0.08)$ was noted at Alexandria shore (752 points). While by moving far from the coastal region, the correlation becomes more stable (Fig. 12).

\subsection{Attenuation coefficient (Kd_490) and Chl-a}

The relationship between Chl-a and the attenuation coefficient seems strong with a correlation factor (r) was 0.99 in all study areas. Additionally, the Kd_490 monthly climatology shows the same pattern of variability as the Chl-a, proving that the phytoplankton cycle is affected by the depth of the euphotic layer. In the same way, most of the study area's waters correspond to Case 2 water indicated by the high values of Kd_490 and Chl-a.

\subsection{Colored dissolved organic matter (CDOM) and Chl-a}

The present study proved a positive correlation between the CDOM and Chl-a while the correlation coefficient (r) was 0.55, 0.64, and 0.67 for El-Max Bay, Alexandria Coast, and Abu Qir Bay, respectively. This can also be observed via the rhythmic variability gained by the averaged CDOM that was partially coinciding with the rhythmicity of $C h l$ $a$ within Case 1. Abu Qir Bay recorded the highest correlation between Chl-a and CDOM, while the lower correlation was noted at El-Max Bay. 


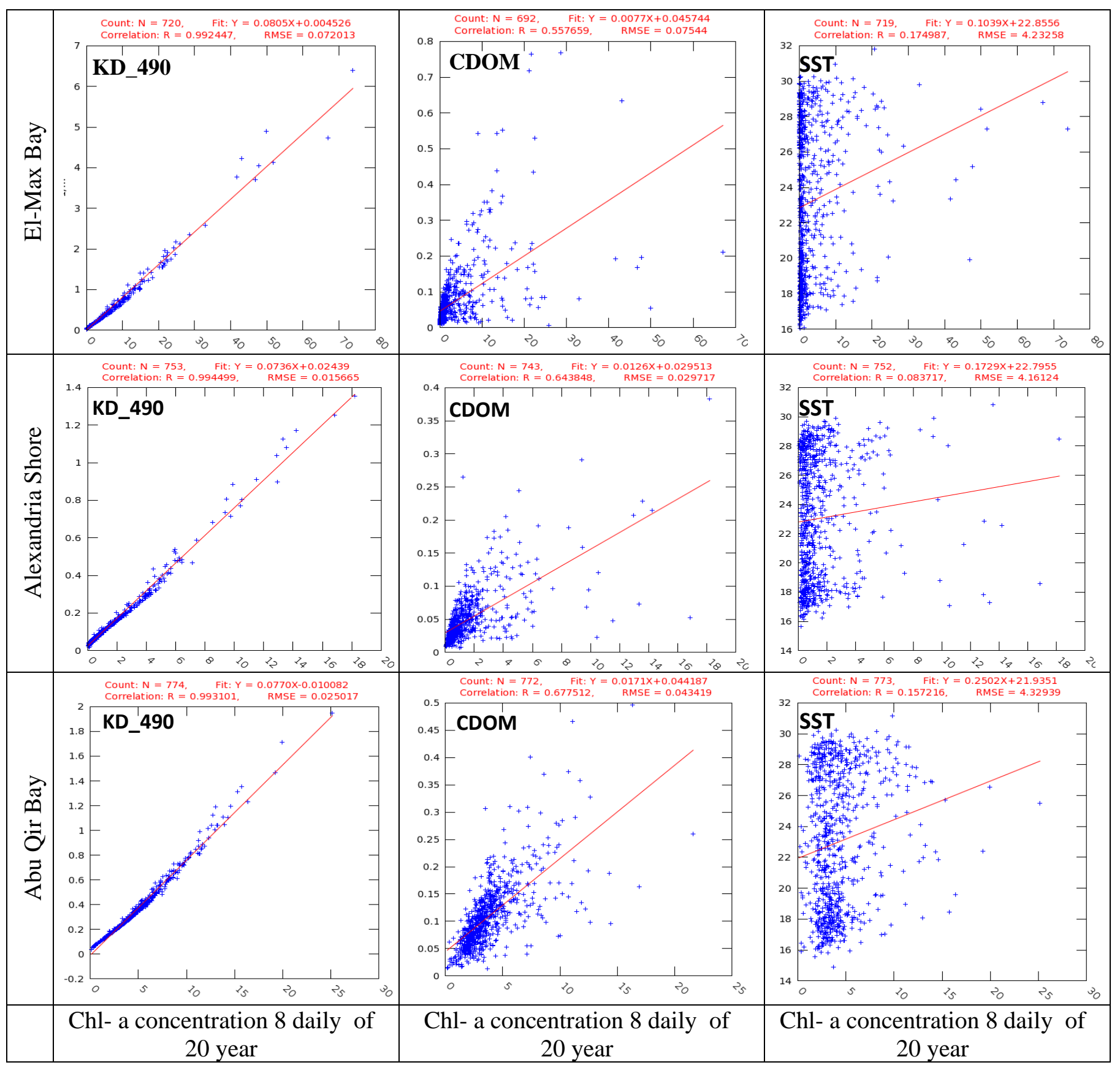

Fig. 12. Person correlation between $C h l-a$ concentration and CDOM, KD, and SST over 20 years at the three studied areas. 
Table 1. An annual average of Nitrate, Phosphate, and Chl- $a$ at the three studied regions over 20 years.

\begin{tabular}{|l|l|l|l|l|l|l|l|l|l|}
\hline \multirow{2}{*}{ Year } & \multicolumn{3}{|c|}{ Nitrate $\boldsymbol{\mu}$ g/ l } & \multicolumn{3}{c|}{ Phosphate $\boldsymbol{\mu g} / \mathbf{l}$} & \multicolumn{3}{c|}{ Chl-a mg/m } \\
\cline { 2 - 10 } & $\begin{array}{l}\text { El- } \\
\text { Max }\end{array}$ & $\begin{array}{l}\text { Alex } \\
\text { Shore }\end{array}$ & $\begin{array}{l}\text { Abu } \\
\text { Qir }\end{array}$ & $\begin{array}{l}\text { El- } \\
\text { Max }\end{array}$ & $\begin{array}{l}\text { Alex } \\
\text { Shore }\end{array}$ & $\begin{array}{l}\text { Abu } \\
\text { Qir }\end{array}$ & $\begin{array}{l}\text { El- } \\
\text { Max }\end{array}$ & $\begin{array}{l}\text { Alex } \\
\text { Shore }\end{array}$ & $\begin{array}{l}\text { Abu } \\
\text { Qir }\end{array}$ \\
\hline $\mathbf{2 0 0 0}$ & 4.00 & 2.00 & 5.00 & 0.20 & 0.30 & 0.10 & 4.32 & 2.31 & 8.21 \\
\hline $\mathbf{2 0 0 1}$ & 1.00 & 1.20 & 0.60 & 0.30 & 0.20 & 0.10 & 4.60 & 2.79 & 7.83 \\
\hline $\mathbf{2 0 0 2}$ & 1.60 & 1.20 & 0.60 & 1.40 & 0.60 & 0.40 & 7.61 & 4.24 & 8.74 \\
\hline $\mathbf{2 0 0 3}$ & 1.70 & 0.60 & 1.60 & 1.00 & 0.40 & 0.30 & 6.30 & 4.08 & 8.89 \\
\hline $\mathbf{2 0 0 4}$ & 2.20 & 0.80 & 1.50 & 0.30 & 0.20 & 0.25 & 6.85 & 3.74 & 9.10 \\
\hline $\mathbf{2 0 0 5}$ & 0.70 & 0.80 & 1.70 & 0.40 & 0.10 & 0.20 & 8.36 & 4.60 & 9.92 \\
\hline $\mathbf{2 0 0 6}$ & 1.00 & 0.50 & 0.70 & 0.60 & 0.10 & 0.15 & 6.89 & 5.30 & 10.53 \\
\hline $\mathbf{2 0 0 7}$ & 0.70 & 0.30 & 0.90 & 0.25 & 0.15 & 0.25 & 6.70 & 4.72 & 9.07 \\
\hline $\mathbf{2 0 0 8}$ & 1.00 & 0.60 & 0.80 & 0.40 & 0.10 & 0.10 & 7.11 & 4.88 & 9.25 \\
\hline $\mathbf{2 0 0 9}$ & 0.60 & 0.80 & 0.40 & 0.50 & 0.20 & 0.15 & 7.61 & 5.17 & 10.86 \\
\hline $\mathbf{2 0 1 0}$ & 0.60 & 0.90 & 5.00 & 0.30 & 0.25 & 0.10 & 5.55 & 3.61 & 8.66 \\
\hline $\mathbf{2 0 1 1}$ & 5.00 & 3.00 & 5.00 & 5.00 & 3.00 & 4.00 & 7.67 & 4.55 & 10.38 \\
\hline $\mathbf{2 0 1 2}$ & 5.30 & 4.00 & 5.50 & 4.00 & 4.00 & 4.00 & 12.42 & 6.64 & 13.82 \\
\hline $\mathbf{2 0 1 3}$ & 5.90 & 4.50 & 5.90 & 3.50 & 3.50 & 4.50 & 11.05 & 6.46 & 14.61 \\
\hline $\mathbf{2 0 1 4}$ & 5.00 & 4.00 & 6.00 & 5.00 & 3.00 & 4.20 & 12.30 & 7.74 & 13.88 \\
\hline $\mathbf{2 0 1 5}$ & 6.00 & 5.00 & 6.00 & 6.00 & 4.00 & 5.00 & 12.86 & 7.17 & 18.05 \\
\hline $\mathbf{2 0 1 6}$ & 5.10 & 4.30 & 7.20 & 4.10 & 2.00 & 4.00 & 10.71 & 5.46 & 11.76 \\
\hline $\mathbf{2 0 1 7}$ & 4.20 & 3.30 & 5.50 & 5.20 & 3.30 & 5.60 & 12.78 & 3.97 & 9.60 \\
\hline $\mathbf{2 0 1 8}$ & 4.00 & 4.00 & 4.00 & 5.50 & 3.00 & 6.00 & 11.13 & 3.01 & 9.56 \\
\hline $\mathbf{2 0 1 9}$ & 7.10 & 6.20 & 5.20 & 6.20 & 4.00 & 7.00 & 15.26 & 3.95 & 9.13 \\
\hline
\end{tabular}

Table 2. The correlation coefficient between $C h l-a$ and nitrate, TP over 20 years

\begin{tabular}{|l|l|l|}
\hline Region & Nitrate & Phosphate \\
\hline El-Max Bay & $\mathrm{r}=0.81$ & $\mathrm{r}=0.91$ \\
\hline Alex Shore & $\mathrm{r}=0.41$ & $\mathrm{r}=0.38$ \\
\hline Abu Qir & $\mathrm{r}=0.53$ & $\mathrm{r}=0.49$ \\
\hline
\end{tabular}




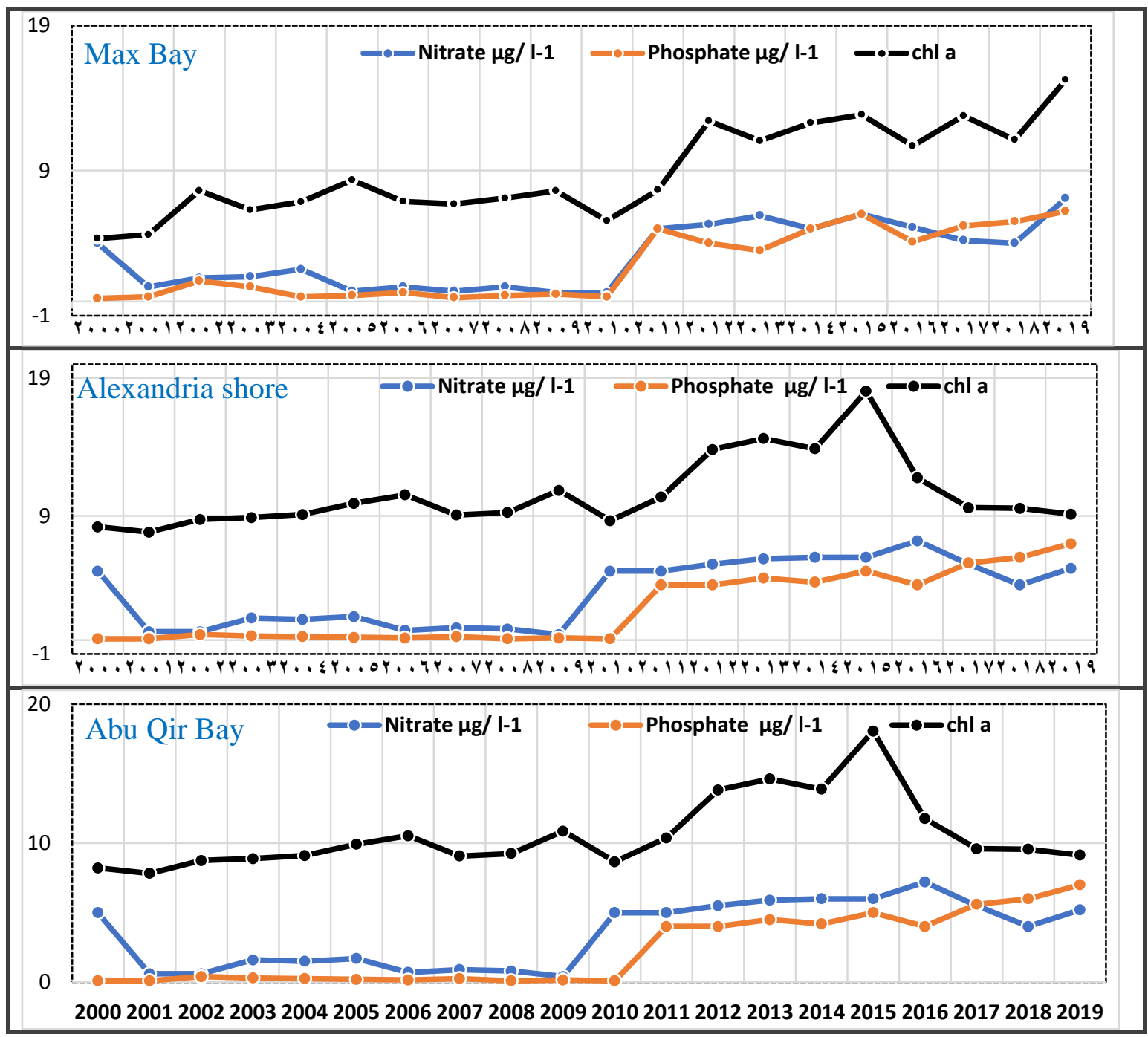

Fig. 13. The relation between nitrate, total phosphate (TP), and Chl- $a$ in three regions over 20 years.

\section{DISCUSSION}

Chlorophyll-a concentration is considered a good phytoplankton productivity indicator and is used as a trophic status indicator. The monthly climatology results proved that the increase of Chl-a concentration was from May to September of each year along the study period (20 years). In general, the rise in the concentration of Chl-a results from global warming raises the sea surface (SST), the rise in the budget for solar irradiance, and nutrient availability such as phosphates nitrates, verified by Krom et al. (2003).

Most days had lower concentrations of Chl-a during autumn and winter than those reported during spring and summer. During spring, Chl-a increases, but in summer it reaches the highest levels along the 20 years with a maximum value, $35 \mathrm{mg} / \mathrm{m}^{3}$ at $\mathrm{Abu}$ 
Qir Bay during 2015, and $40 \mathrm{mg} / \mathrm{m}^{3}$ at El-Max Bay during 2019. The increased summer values of Chl- $a$ were recorded in all studied regions. The present results showed a high concentration of Chl-a during the hot season which confirmed by several authors (Faragallah et al., 2009; Abo-Taleb et al., 2015; Abo-Taleb et al., 2016; El Raey and Abo-Taleb, 2019).

An analysis of ocean colour satellite imagery (GlobColour dataset with the MedOC4 algorithm applied) between 1997 and 2006 confirmed the return of the Nile bloom and its predominance along the whole Nile Delta shelf in winter and spring with an upward trend for the mean surface Chl-a concentrations in the coastal waters off the Nile Delta and no significant trend for the outer shelf (Lavender et al. 2009). While not all years have the same values and identical dramatic increasing, for instance, the highest blooming according to the current work was during 2015, While Ali Salem Dango (2015) recorded that phytoplankton had the greatest numerical abundance in autumn $2013\left(227.3 \times 10^{3}\right.$ units $\left.1^{-1}\right)$ and spring $2014\left(37.5 \times 10^{3}\right.$ units $\left.1^{-1}\right)$, the lowest density in summer $2014\left(8.4 \times 10^{3}\right.$ units $\left.1^{-1}\right)$ was observed.

As in many estuaries (e.g., Gayoso, 1998), the spring bloom was the most characteristic event in the annual phytoplankton cycle. However, the present study disagrees with the previously mentioned pattern and deviates to be during the summer where the strongest bloom occurs. Fortunately, our observation matched with Abdel Aziz et al. (2011), finding an increase of micro flagellates and dinoflagellates numbers during summer for Rosetta Estuary of the Mediterranean Sea. Several authors (e.g., Wirtz and Wiltshire, 2005) stressed the critical role of the cessation of mixing in summer for the predominance of flagellates in marine ecosystems. The phytoplankton production's annual cycle as characterized by a massive bloom of diatoms-chlorophytes in late spring, minor peaks of diatoms Phyto flagellates chlorophytes during summer-early autumn, and relatively lower phytoplankton density in winter (Mikhail,2008).

The result of an annual analysis of $C h l-a$ along the study period showed two upward trends. The first mild trend was from 2000 to 2010 as a result of the effects of continuous and ever-increasing addition of organic and inorganic nutrients from a dramatic increase in the human population and a subsequent dramatic extension of the urban water supplies and sewage collection systems in Lower Egypt and the northern 
parts of the Nile Delta since the early 1980s. There are over $3 \times 10^{6}$ sanitary sewage industrial wastewater discharged daily from Alexandria city directly to the coastal waters off the western coasts of the Delta (Halim and Shouk, 2000). The second trend started from 2011 to 2019, with a highly increased rate of Chl-a. It occurs after the revolution of January 25, 2011, where informal housing and foul drainage on canals increased from agricultural, industrial, fish farms and sanitary drainage without state control, as well as the absence of law enforcement, which led to an increase in the level of nutrients which lead to increasing the numbers of phytoplankton (Abo-Taleb et al., 2016).

The phytoplankton blooming, expressed by Chl-a, was very obvious and more pronounced near the outlets of the Egyptian coastal lakes and urban outfalls so, the Chl$a$ was represented by very high values at El-Max Bay and Abu Qir Bay than Alexandria shore, also it increased in the eastern and western harbour than Dekhaila Harbor during some years, The variability in space indicated the area in front of the drain mouth is relatively less productive than the entire Bay, as confirmed by Mikhail (2008), hence, $C h l-a$ increase in semi-enclosed regions not in open water.

The correlation between the Chl- $a$ and SST data is very low, while the highest value was noted at El-Max Bay, on the other hand, Alexandria shore recorded the lowest correlation between Chl- $a$ and SST, this may be attributed to the unstable water condition along the Egyptian Mediterranean coast due to the huge number of freshwater canals, drains, sea-lake connections and estuaries which cause continuous mixing conditions result in unstable water temperature which may explain the unclear correlation between Chl- $a$ and SST along the coastal water (Abou Zaid $\boldsymbol{e t}$ al.,2014 and Abo-Taleb et al., 2015). In addition, this result can be associated with many other variables, such as phot acclimation, water stratification and the optimum temperature of the flowering phytoplankton organisms (Xing et al., 2014). On the other hand, the correlation between Chl- $a$ and the attenuation coefficient seems to be strongly positive, where it was recorded a significantly high correlation coefficient $r=0.9$ in all the regions of the study area. In the same way, most of the study area waters correspond to Case 2 water. The high values of Kd 490 and Chl-a well suggest turbid Case 2 water hotspots and a high load of suspended materials was present at the drain outlets, In extremely turbid zones where the euphotic layer appears shallow, Chl-a tends to be influenced by 
the suspended problems, so non-limiting nutrients cause algal blooms in very turbid water (Harding et al., 1986; Cloern, 1987; Lehman, 1992).

In the current analysis, the positive, mid-strengthening correlation coefficient between the CDOM and Chl- $a$ in the three areas studied can also be observed through the rhythmic variability obtained by the average CDOM, partially coinciding with the rhythmicity of Chl-a in Case 1, Abu Qir Bay reported the highest correlation. At the same time, El-Max Bay showed the lower one which reflects the high load of organic matter at Abu Qir Bay coming from the connection between the Bay and Edku Lake at its meddle part as well as the connection of the Bay with the Rosetta Estuary at its eastern side (Abo-Taleb et al., 2017 and El-Damhogy et al., 2019). Theoretically, the existence of CDOM is correlated with the activity of phytoplankton in Case 1 water, but many findings have suggested the global and regional divergence of CDOM and phytoplankton (Morel et al., 2010; Xing et al., 2014). The rise in CDOM in coastal water to high values may be attributed to water discharge and drains along with the coastal areas. While in the open waters, the phytoplankton bloom activity alone is the principal contributor to the index variability. One of the most important factors that affect phytoplankton blooming is the nutrient salts, nitrate and phosphate, as they considered a necessary fertilizer for the growth of phytoplankton, the annual concentrations of nitrate and phosphate were strongly correlated positively with the $C h l$ $a$, and this notice by the recorded higher levels of both after the year 2011 in a similar pattern in the three studied regions.

\section{REFERENCES}

Abd Allah, A. M.; Sharaf El-Din, S. H. and Shereet, S. M. (2006). Analysis of wave observations and wave transformations in Abu- Qir Bay, Egypt. Egy. J. Aquat. Res., 32(1): 22 - 23.

Abdel Aziz, N.E.; Aboul Ezz, S.M.; Abou Zaid, MM and Abo-Taleb, H.A. (2011). Temporal and spatial dynamics of rotifers in Rosetta Estuary, Egypt. Egyptian Journal of Aquatic Research. 37(1): 59-70.

Abdel-Moneim, M. A. and Shata, M. A. (1993). Study of some heavy metals in AbuQir Bay under the effect of industrial effluents. Bull of high Inst. of Public Health, XIII (3): 675 - 695. 
Abo-Taleb, H.A.; Aboul Ezz, S.M.; Abdel Aziz, N.E.; El Raey, M. and Abou Zaid, MM. (2016). Detecting Marine Environmental Pollution by Biological Beacons and GIS program. Journal of Fisheries Science.com. 10(4): 069-083.

Abo-Taleb, H.A.; El Raey, M.; Abou Zaid, MM.; Aboul Ezz, S.M. and Abdel Aziz, N.E. (2015). Study of the physico-chemical conditions and evaluation of the changes in eutrophication-related problems in El- Max Bay. African Journal of Environmental Science and Technology. 9(4): 354-364. http://dx.doi. org/ 10.5897/AJEST2014.1823

Aboul Ezz, S.M.; Abdel Aziz, N.E.; Abou Zaid, MM.; El Raey, M. and Abo-Taleb ,H.A. (2014). Environmental assessment of El-Max Bay, Southeastern Mediterranean by using Rotifera as a plankton bio-indicator. Egyptian Journal of Aquatic Research. 40 (1): 43-57. http://dx.doi.org/10.1016/j.ejar.2014.03.005

Ali Salem Dango, E. (2015). Spatial and Temporal Variations of Phytoplankton Communities and Environmental Conditions Along the Coastal Area of Alexandria. Science Research, 3(6), 273. https://doi.org/10.11648/j. sr.20150306. 12.

Andersen, JH.; Schlüter L. and Ertebjerg G. (2006). Coastal eutrophication: recent developments in definitions and implications for monitoring strategies. J Plankt Res 28:621-628.

Ansari, A. A.; Gill, S. S.; Lanza, G. R. and Rast, W. (2011). Eutrophication: Causes , consequences and control. Springer, Dordrecht, pp 143-170

Austin, R.W. and Petzold, T.J. (1981). The determination of the diffuse attenuation coefficient of sea water using the Coastal Zone Color Scanner. Oceanography from space, vol. 13. Plenum Press, 239-256, http://dx.doi.org/10.1007/978-14613-3315-9_29

Bosc, E.; Bricaud, A. and Antoine, D. (2004). Seasonal and interannual variability in algal biomass and primary production in the Mediterranean Sea, as derived from 4 years of SeaWiFS observations. Global Biogeochemical Cycles, 18, Article \# GB1005.

Brando, V.; Dekker, A.; Park, Y. and Schroeder, T. (2012). Adaptive semianalytical inversion of ocean colour radiometry in optically complex waters. Appl. Optics 51 (15), 2808-2833, http://dx.doi. org/10.1364/AO.51.002808.

Bricaud, A.; Bosc, E. and Antoine, D. (2002). Algal biomass and sea surface temperature in the Mediterranean Basin - intercomparison of data from various satellite sensors, and implications for primary production estimates. Remote Sensing of Environment, 81(2-3): 163-178.

Bricker, S. B.; Clement, C. G.; Pirhalla, D. E.; Orlando, S. P. and Farrow, D. R. G. (1999). National Estuarine Eutrophication Assessment: Effects of nutrient enrichment in the Nation's Estuaries. NOAA, National Ocean Service, Special 
Projects Office, and the National Centers for Coastal Ocean Science. Silver Spring, MD. $71 \mathrm{pp}$.

Cloern, J. E. (2001). Our evolving conceptual model of the coastal eutrophication problem. Marine Ecol. Prog. Ser. 210: 223-253.

Cloern, J.E. (1987). Turbidity as a control on phytoplankton biomass and productivity in estuaries. Cont. Shelf Res. 7 (11-12), 1367-1381, http://dx.doi.org/10.1016/ 0278-4343(87)90042-2.

De Jonge, VN.; Elliott, M. and Orive, E. (2002). Causes, historical development, effects, and future challenges of a common environmental problem: eutrophication,Hydrobiologia,475/476, 1- 19. http://dx.doi.org/ 10.1023/A: 1020 366418295

Dierssen, H. M. (2013). Earth System Monitoring. Earth System Monitoring, November. https://doi.org/10.1007/978-1-4614-5684-1.

Dorgham, M.M. (2011). Eutrophication problem in Egypt. Book: Eutrophication: causes, consequences and control, Ch. 8:171-194.

El Kafrawy, S. B. (2017). Monitoring the Environmental Changes of Mariout Lake during the Last Four Decades Using Remote Sensing and GIS Techniques. MOJ Ecology \& Environmental Sciences, 2(5), 2-5. https://doi.org/10.15406/ mojes.2017.02.00037

El Raey, M. and Abo-Taleb, H. (2019). A Survey of Satellite-borne Biosensors Applications. In: Advances in Environmental Monitoring and Assessment. Suriyanarayanan Sarvajayakesavalu, Editor. Intechopen, London. UK ISBN 978953-51-6946-8. https://doi.org/10.5772/intechopen.85916

El- Sherif, Z. (2006). Effects of Industrial, Touristic and Marine Transport on Physical, Chemical and Biological Characteristics of Water and Fish Populations, West of Alexandria.

El-Damhogy, K.A.; Abo-Taleb, H.A.; Ahmed, H.O.; Aly-Eldeen, M.A. and AbdelAal, M.M. (2019). The relationship between the concentrations of some heavy metals in the water of Abu-Qir Bay and within the tissues of the blue crab Portunus pelagicus. Egyptian Journal of Aquatic Biology \& Fisheries. 23(3): 347359. https://doi.org/10.21608/ejabf.2019.46450.

El-Kafrawy, S. B.; Khalafallah, A.; Omar, M.; Khalil, M. M. H.; Yehia, A.and Allam, M. (2015). An integrated field and remote sensing approach for water quality mapping of Lake Burullus, Egypt. International Journal of Environmental Science and Engineering (Ijese), 6(February), 15-20.

El-Zeiny, A. and El-Kafrawy, S. (2017). Assessment of water pollution induced by human activities in Burullus Lake using Landsat 8 operational land imager and GIS. Egyptian Journal of Remote Sensing and Space Science, 20, S49-S56. https://doi.org/10.1016/j.ejrs.2016.10.002. 
Faragallah, H. M.; Tadros, H. R. Z. and Okbah, M. A. (2009). Nutrient salts and chlorophyll-a during short term scale in the Eastern Harbour, Alexandria (Egypt), Egyptian Journal of Aquatic Research, 35(3): 243-250.

Faragallah, H.M. (2004). Chemical fractionation of phosphorus and some heavy metals in suspended matter in water column and sediment in Abu- Qir Bay., Egypt. Ph.D. Thesis, Faculty of Science, Alexandria University. pp: 347.

Fisher, TR.; Melack, JM. and Grobbelaar, JU. (1995). Nutrient limitation of phytoplankton and eutrophication of inland, estuarine, and marine waters. In: Tiessen H (ed) Phosphorus in the global environment. Wiley, New York, NY, pp 301-322.

Gayoso, A. M. (1998). Long-term phytoplankton studies in the Bahia Blanca Estuary, Argentina, ICES. Journal of Marine Science, 55: 655-660.

Gharib, S. M. and Dorgham, M. M. (2006). Eutrophication stress on phytoplankton community in the Western Harbour of Alexandria, Egypt. International Journal of Oceans and Oceanography, 1(2), 261-273.

Harding, L.W.; Meeson, B.W. and Fisher, T.R. (1986). Phytoplankton production in two east coast estuaries: photosynthesis-lightfunctions and patterns of carbon assimilation in Chesapeake and Delaware bays. Estuar. Coast. Shelf Sci. 23 (6), 773 - 806, http://dx.doi.org/10.1016/0272-7714(86)90074-0.

Khalil, M. T. (2014). Environmental management of Burullus Protectorate (Egypt), with special reference to fisheries. Int. J. Env. Sc. \& Eng., 4: 93- 104. Burullus Protected Area is located on the Mediterranean coast of the northern Delt. November 2013, 93-104.

Kholeif, S. E. (2008). Dinoflagellate cysts as bio-indicator of marine pollution in bottom sediments of Abu-Qir Bay, Alexandria coastal water, Egypt. Egy. J. Aquat. Res., 34(3): 110 - 126.

Krom, MD.; Groom, S. and Zohary, T. (2003) The Eastern Mediterranean. In: Black KD, Shimmield GB (eds) The biogeochemistry of marine systems. Blackwell Publishing, Oxford.

Lavender, S. J.; Moufaddal, W. M. and Pradhan, Y. (2009). Assessment of temporal shifts of chlorophyll levels in the Egyptian Mediterranean shelf and satellite detection of the Nile bloom. Egyptian Journal of Aquatic Research, 35(2), 121135 .

Lee, Z.P. (2005). A model for the diffuse attenuation coefficient of downwelling irradiance. J. Geophys. Res. 110 (C2), http://dx. doi.org/10.1029/2004jc002275.

Lehman, P.W. (1992). Environmental factors associated with longterm changes in chlorophyll concentration in the Sacramento-San Joaquin delta and Suisun bay, California. Estuaries 15 (3), 335 - 348, http://dx.doi.org/10.2307/1352781.

Mann, K.H. and Lazier, J.R.N. (2006). Dynamics of Marine Ecosystems: BiologicalPhysical Interactions in the Oceans, 3rd edn. Black- well Publ., Malden, 496 pp. 
Mannino, A.; Russ, M.E. and Hooker. (2008) SB Algorithm development and validation for satellite-derived distributions of DOC and CDOM in the US Middle Atlantic Bight. J. Geophys. Res. 113, 1-19.

Mikhail, S. K. (2008). Dynamics of estuarine phytoplankton assemblages in El-Max Bay, Alexandria (Egypt): Influence of salinity gradients. In Aquat. Biol. \& Fish (Vol. 12).

Morel, A.; Claustre, H. and Gentili, B. (2010). The most oligotrophic subtropical zones of the global ocean: similarities and differences in terms of chlorophyll and yellow substance. Biogeosciences 7(10), 3139-3151, http://dx.doi.org/10.5194/ bg-7-3139-2010.

Moufaddal, W.M. (2005). state of coastal water along the Nile Delta front, Egypt, as revealed by satellite imagery. International Journal of Remote Sensing, 26(25): 4877-4853.

NOWPAP CEARAC (2005). Integrated Report on Ocean Remote Sensing for the NOWPAP Region.

Richlen, M.L.; Morton, S.L.; Jamali, E.A.; Rajan, A. and Anderson, D.M. (2010). The catastrophic 2008-2009 red tide in the Arabian Gulf region, with observations on the identification and phylogeny of the fish-killing dinoflagellate Cochlodinium polykrikoides. Harmful Algae, 9: 163-172.

Saad, M.A.H. and Younes, W.A.N. (2006). "Role of Phosphorus and nitrogenous species in water quality of a coastal Egyptian heavily polluted Mediterranean basin. International Journal of Oceans and Oceanography, ISSN 0973-2667.

Said, M. A; Ennet, P.; Kokkila, T. and Sarkula, J. (1995). Modeling of transport processes in Abu Qir Bay, Alexandria (Egypt). Proceed of the 2nd Internet Conf. on the Medit. Coast. Environ., MEDCOAST 95, Tarragona, Spain: 1673-1687.

Segerson, K. and Walker, D. (2002). Nutrient pollution: an economic perspective. Estuaries 25:797-808.

Wirtz, KW. and Wiltshire, K. (2005). Long-term shifts in marine ecosystem functioning detected by inverse modeling of the Helgoland Roads time-series. $\mathbf{J}$ Mar Syst 56(3-4):262-282.

Xing, X.; Claustre, H.; Wang, H.; Poteau, A. and D'Ortenzio, F. (2014). Seasonal dynamics in colored dissolved organic matter in the Mediterranean Sea: patterns and drivers. Deep-Sea Res. Pt. I 83,93-101, http://dx.doi.org/10.1016/j.dsr.2013.09.008.

Youssef, D. H. and Masoud, M. S. (2004). Behavior of some acid-based indicators in some Egyptian aquatic environments. Bull. Chem. Tech. Maced., 23 (1): 37- 46. 


\section{ARABIC SUMMARY}

\section{تقييم طويل الأمد لمشكلة التظذية الفائقة (التخثة) باستخام بيانات الأقمار الصناعية متعدة المجس على طول}

خليج المكس وساحل الإسكندرية وخليج أبو قير ، مصر.

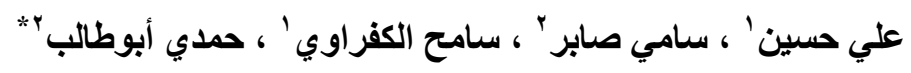

$$
\begin{aligned}
& \text { 1. الهيئة القوميه للإستشعار من بعد و علوم الفضاء ـ القاهرة - مصر. } \\
& \text { r. كلية العلوم ، جامعة الأزهر - القاهرة - مصر. }
\end{aligned}
$$

تتعرض المياه الساحلية بالإسكندرية وخليج أبو قير لتغيرات مكانية وزمانية في الإنتاجية الأولية والخصائص الفيزيائية والكيميائية على المدى القصير والطويل بسبب الصرف المستمر والمتزايد للمغذيات العضوية وغير

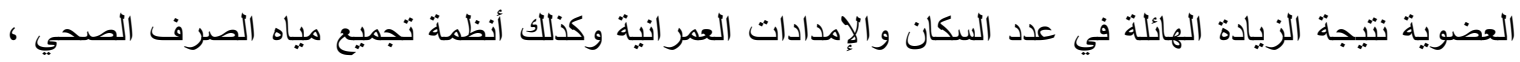

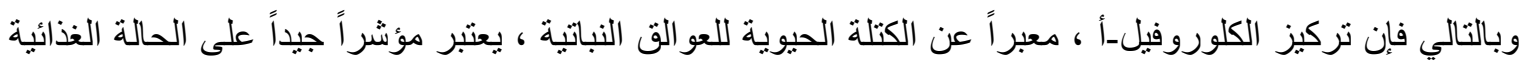

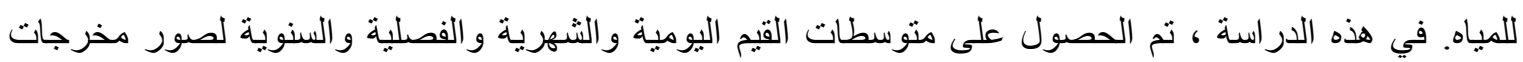

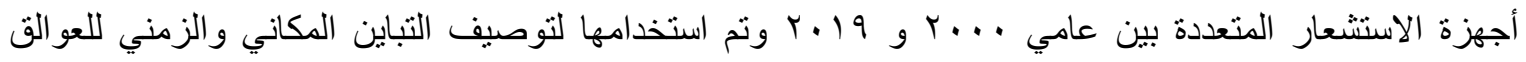
النباتية في المناطق الحيوية المختلفة من المنطقة الساحلية المصرية. تصف النتائج التي تم الحصول عليها أن الحيود

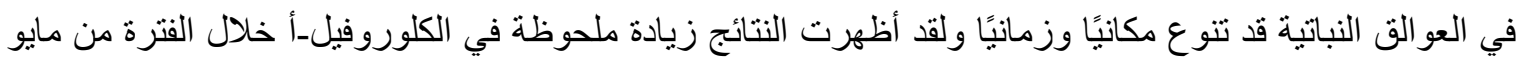
إلى سبتمبر (الربيع و الصيف) من كل عام ، وكان الصيف دائيًا أعلى من الربيع.

أظهرت بيانات الكلوروفيلـأ السنوية اتجاهان تصاعديان مزدوجان حدثا خلال فترة الدراسة ، كان الأول من عام

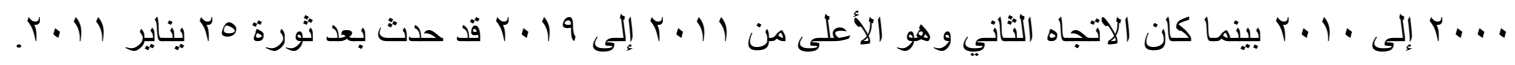

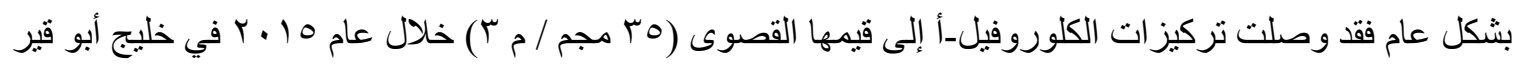

$$
\text { و • مجم / مَّ في خليج المكس خلال } 2019 .
$$

كان تركيز الكلوروفيلـأ مرتفعًا و أكثر وضوحًا بالقرب من منافذ البحير ات الساحلية الصصرية والمصارف الحضرية

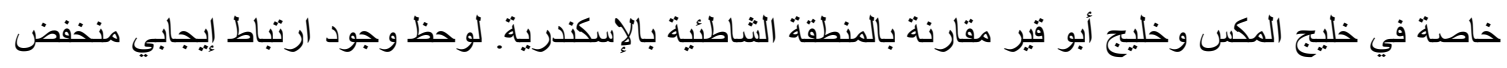
بين الكلوروفيل-أ ودرجة حر ارة سطح البحر (SST) ، من ناحية أخرى ، يبدو أن الارتباط بين الكلوروفيلـأ ومعامل

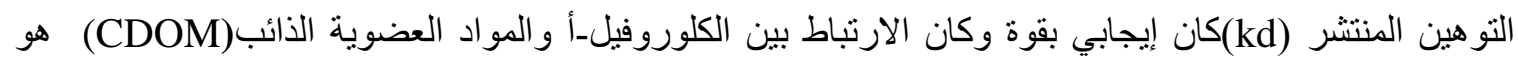
الأقوى علي الإطلاق ، وكذلك كان الارتباط بين الكلوروفيلـأ والنترات و الفوسفات مو جبنًا بثدة. 